\title{
Visit Batang Heaven of Asia: Tourism Marketing Communication
}

\author{
Danang Satrio \\ \{danangsatrio3003@yahoo.com\} \\ Faculty of Economics, Pekalongan University
}

\begin{abstract}
The existence of the tourism sector has a positive impact on an area. Batang Regency has enormous potential in tourism and culture. The condition of Batang Regency is a combination of coastal areas, lowlands and mountains. Today more and more research shows the importance of a marketing communication strategy in the field of tourism and culture. This research will show where the Batang Heaven of Asia Visit video is interpreted in depth with the concept of Tri Hita Kirana which is able to summarize all the potential in Batang Regency and then package it as an alternative medium to promote tourism in Batang Regency. Aside from being an alternative media for promotion of Batang Regency, this video also has goals that are divided into two aspects, namely rational and irrational. In this video is expected to provide a detailed explanation of the meaning of the signs in the video being studied and see how far the success of tourism marketing communication.
\end{abstract}

Keywords: Tourism, Marketing Communication, Tourism Marketing Communication

\section{Introduction}

In the development of the world of tourism today, the type of tourism in Indonesia that is being favored is tourism based on the environment and history-based tourism. In addition, the tourism sector is a potential sector to be developed as one of the sources that encourage and accelerate economic growth because there will be new jobs and new employment opportunities for the community so that economic income and the level of community welfare will be guaranteed. However, its management and development in Indonesia still lack attention. With the digitalization of mass communication technology is now growing rapidly, it certainly helps meet the needs of communication information by the public. The substantive element of marketing communication is to inform, introduce, provide understanding, popularize, persistently persuade market targets to be interested in the product being offered, ultimately increasing the number of sales.

Batang Regency is located at $6^{\circ} 51$ ' 46 "to $7^{\circ} 11^{\prime} 47^{\prime \prime}$ South Latitude and between $109^{\circ}$ 40 ' 19 "to $110^{\circ} 03^{\prime}$ '06" East Longitude on the north coast of Central Java and is on the main route connecting Jakarta - Surabaya. Transportation flows and high mobility in the pantura lane provide convenience to get to Batang Regency. Its territorial borders are north of the Java Sea, east of Kendal Regency, south of Wonosobo Regency and Banjarnegara Regency, west of the City and Pekalongan Regency. The condition of Batang Regency is a combination of coastal areas, lowlands, and mountains. With this condition, Batang Regency has enormous potential in tourism and culture. 
Tourism is seen as an activity that has a multidimensional set of development processes. Based on data obtained through the Central Java Statistic Agency, public interest in coming to the number of tourist attractions in Central Java is increasing, not only local tourists but also foreign tourists who enliven tourism in Indonesia in general and in Central Java in particular . The increase in the number of tourists in an area is caused by the needs of millennial-era people who prioritize holidays as part of their lifestyle and also as a reliever of fatigue from daily routines. The digital era makes it easy for tourists to get all the information needed in their vacation to a tourist destination. The following statistical data showing the development of the number of tourists in Central Java can be see $n$ in table 1;

Table 1 Number of International and Domestic Visitors in Central Java Province, 2011-2016

\begin{tabular}{|c|c|c|c|}
\hline \multirow{2}{*}{ Year } & \multicolumn{2}{|c|}{ Visitors } & \multirow{2}{*}{ Total } \\
\cline { 2 - 3 } & International & Domestic & \\
\hline 2011 & 392.895 & 21.838 .351 & 22.231 .246 \\
\hline 2012 & 372.463 & 25.240 .021 & 25.612 .484 \\
\hline 2013 & 388.143 & 29.430 .752 & 29.818 .752 \\
\hline 2014 & 419.584 & 29.852 .679 & 30.271 .679 \\
\hline 2015 & 375.166 & 31.432 .246 & 31.807 .246 \\
\hline 2016 & 578.924 & 36.899 .700 & 37.478 .700 \\
\hline
\end{tabular}

Source: Regional Culture and Tourism Service of Central Java Province 
The table 1 shows the number of foreign and domestic tourists in Central Java increased significantly from year to year, only in the period of five years the number of tourists increased by almost 30 percent, this was due to the ease of accessing tourism information and services. In conducting marketing communication, digitalization can facilitate and expand the reach of marketing itself. The marketing communication process has an important role, this is due to no matter how good the strategic plan has been designed, if the marketing communication process is not carried out effectively and efficiently in accordance with the objectives, the final results will not be as expected. The relationship between marketing strategy and communication becomes important because in essence this relationship is a continuous creative step that is strived to achieve the best marketing target in order to achieve maximum target satisfaction [1]. Similarly, the implementation of marketing communication strategies in the tourism sector.

Marketing in tourism will not forget about advertising, promotion and effective publicity. Without it, all that the consumer will offer is not responded to by the consumer, therefore in the marketing planning plan, advertising, promotion, and publication activities are needed. Activities to carry out marketing strategies in the tourism sector require complete and precise information in making decisions to offer tourism industry products. In modern marketing the development of tourism marketing is carried out through the promotion of products offered in accordance with the intended target market, meaning that the marketing objectives become effective. The products offered can be in accordance with the needs and desires of the intended target market.Based on the results of the background description, the authors are interested in analyzing more in how tourism marketing communication is used in increasing tourist visits through the video "Visit Batang Heaven of Asia". Based on the description of the background of the problem, the formulation of the problem is how is the video marketing communication "Visit Batang Heaven of Asia" in increasing tourist visits? Research Objectives To analyze in depth the video marketing communication "Visit Batang Heaven of Asia" in increasing the number of tourist visits.

\section{Study of Literature}

\subsection{Tourism Marketing}

Tourism destinations or brand destinations of a country or a particular region are a problem that is still very new, both in the study of tourism, marketing, communication and public policy in a country. In various countries, the tourism sector has become a very interesting social and economic phenomenon, where communication studies are a very strategic area of study when viewed from this phenomenon. Tourism, as one of the special service products, includes several specific things that must be well understood if a tourism business is willing to maximize its potential for success. It must be understood that if we discuss tourism products, we also discuss products that are closely related to hospitality and leisure. Understanding the complexity of the nature of tourism product services is an essential prerequisite for achieving successful marketing. As a service or service product, tourism has several dimensions that are very different from the general product dimensions that we encounter in the everyday market, namely: a. Intangibility b. Perishability c. Inseparability.

Tourism marketing is all activities to meet demand and supply, so that buyers get satisfaction and sellers get maximum profit with minimal risk [2] Buyers in tourism activities are tourists, while sellers are tourism managers. With tourism marketing, the manager can find out what types of tourism products are in accordance with the wishes and needs of tourists, so that the management can design and provide the right products to tourists. The success of tourism marketing activities is supported by good marketing communication.

\subsection{Tourism Marketing Communication}

The concept of Tourism Communication is to revive a variety of tourism is a dynamic activity involving many people and business fields [3]. The concept of good Tourism Communication will attract many tourists to visit the place. The success of tourism marketing communication in relation to destinations is the delivery of a message about a tourism destination to the right customers, and in the right way. Marketing communication requires the existence of a brand or branding to be able to connect the organization with prospective buyers. The characteristics of tourism marketing communication in the marketing process are aimed at potential consumers. Tourism has the following characteristics: no tangible, cannot be stored processes between production and consumption occur together, is a combined component to be said to be a tourism product.[4] 
Tourism marketing communication aims to achieve the three stages of change shown to consumers. the first stage to be achieved from the marketing communication strategy is the stage of changing knowledge (knowledge), in this change consumers know of the existence of a product, for what product was created, and addressed to whom. Thus the message shows important information from the product. The second stage is a change in attitude in the consumer behavior, this change in attitude is determined by three elements called by Sciffman and Kanuk, [5] referred to as the tricomponent attitude changes which shows that the stage of attitude change is determined by three components, namely cognition (affection), affection (feeling ), and conation (behavior). Every time Indonesian consumers change a little with a little towards a stage called social knowledge, the third stage is even more dangerous for every advertising designer who intends to fool consumers. It needs to be realized that these ethical boundaries do not really mean to limit the intensity of ideas, even motivate higher levels of advertising innovation and creativity and help creative people to provide an advertisement. So the core of the Marketing Communication objectives is: a. Generating a desire for a product category b. Brand Awareness c. Intention d. Facilitate Purchases.

\section{Method of Research}

The research method used in this study is qualitative. This research process involves important efforts, such as asking questions and procedures, collecting specific data from participants, analyzing data inductively from themes that are specific to general themes, and interpreting the meaning of data [6]. A qualitative approach is especially feasible to examine attitudes or behavior in a rather artificial environment, such as in surveys or experiments. Qualitative research does not prioritize the population and even the population or sampling is very limited [7]. Based on the level or method of analyzing research data using descriptive types or types of research, this research aims to make a systematic, factual and accurate description of the facts and characteristics of a particular population or object.

\section{Result and Discussion \\ 4.1 Overview of Batang Heaven of Asia Visit}

Visit Batang Heaven Asia is a tourism promotion through a video that communicates the concept of Tri Hita Kirana in its content. The concept of Tri Hita Kirana consists of three words, tri, meaning, three, hita means welfare and Kirana means, cause. So Tri Hita Kirana (THK) means three components or elements that cause welfare. The three components of THK are closely related to one another. The three components of THK according to Sudarta [8] include Parahyangan (the harmonious relationship between humans and God Almighty), Pawongan (the harmonious relationship between humans and humans), and Palemahan ( the harmonious relationship between humans and nature and ancestral heritage). With the promotional video with the concept of Tri Hita Kirana being able to summarize all the potential in Batang Regency then package it as an alternative medium to promote tourism in Batang Regency. Aside from being an alternative media for promotion of Batang Regency, this video also has goals that are divided into two aspects, namely rational and irrational. In the irrational aspect, it is more targeted at one's emotional condition, namely to persuade people who see a series of pictures of the natural beauty that this island has. So that it not only creates a sense of admiration by them but also can cause curiosity and interest to feel the direct tour in the District, Batang. Whereas in the rational aspect, this video aims to inform the potential of the District. This trunk is a means of promoting new tourist destinations in Indonesia 


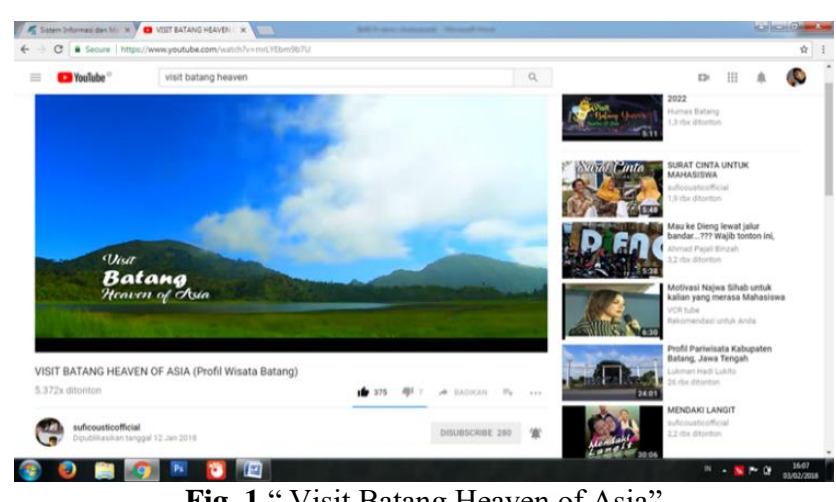

Fig. 1 "Visit Batang Heaven of Asia"

\subsection{Tourism marketing techniques}

In tourism marketing communication it is necessary to pay attention to marketing techniques so that the products sold are marketable. Promotion is one of the marketing mix variables used by companies to communicate with the market. Promotion is also often said to be a continuing process because it can lead to a series of subsequent activities. Marketing communication is needed by the organization with the aim of informing the product, reminding, and influencing potential customers to want to change to make a purchase. The role of the media in performing imagery or visualization is becoming increasingly important in tourism marketing communication because of the unreality of its form.

The importance of information in marketing communication has become a wider concern. In its development, information will never be neutral, information is held for a specific purpose, sometimes information contains a political ideology of a product. In the formulation of a marketing communication strategy, identification of communication is needed as to what is needed by the organization or individual in conducting group communication or target market. The difference in communication perspectives is also an important consideration, in designing tourism marketing communication models. In reality the tourism industry must be dynamic in responding to changes in consumer needs, as well as environmental developments that occur. Competition between destinations will also affect marketing communication management. From the tourism marketing technique, the form of communication that is built is mass communication, group communication, and individuals by always paying attention to ethics, etiquette and morals, and must be interesting, so that the marketing communication goals can succeed, namely changing knowledge, changing attitudes, and changing the behavior of consumers 4.3. Achievement Analysis.

The video distribution that has been made by researchers to the public is done by utilizing social media. According to Van Dijk in Nasrullah [9] social media is a media platform that focuses on the existence of users who facilitate their activities and collaborate. Therefore, social media can be seen as an online medium (facilitator) that strengthens user relationships as well as a social bond. The social media used in the distribution of videos in youtube, this is due to the spread in the media because it is proven to be more effective and efficient. Based on the screenshot on the youtube publication, it is known that the response and public assessment of the teaser video works that have been produced get good appreciation. Within a month of launch, more than 12.056 viewers were watched. This was further strengthened by the many positive ratings or comments on the video. 


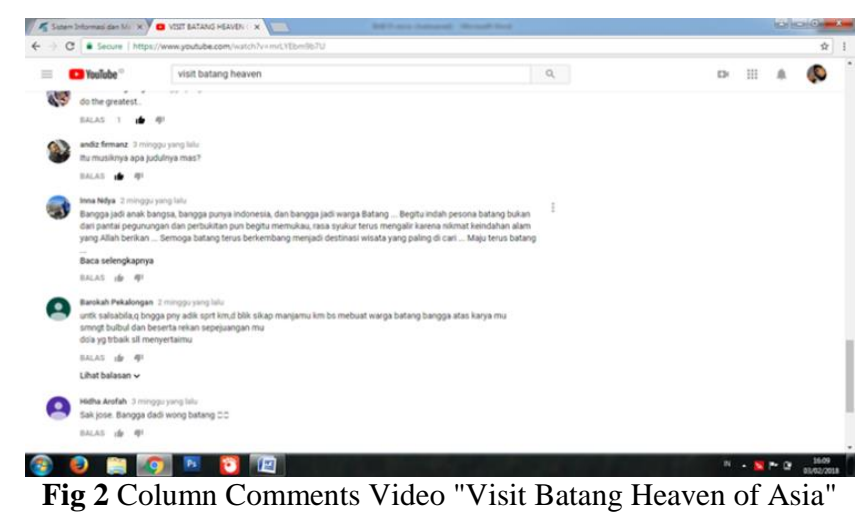

Most viewers made positive comments regarding the video, and this included: Praise Many netizens have praised the video, and this includes: 1) the contents of a video showing the natural beauty of the Kab. Batang, and make the viewer interested in being able to visit the place; 2) taking pictures that are professional enough and make video packaging artistic and classy. Many viewers praised Batang Regency as a beautiful, nice, charming, beautiful, beautiful place, tourism paradise, and tourism place that must be visited by anyone. From these comments it can be concluded that the video "Visit Batang Heaven of Asia" that has been made is able to gain the sympathy and attention of the community .. Besides that this promotional video has invited concern from the community to continue to promote Indonesian tourism, especially Batang Regency.

\section{Conclusion}

In developing tourism promotion, it should be noted that the modern dimension is dominated by audio visual dimensions, so "Batang Heaven Of Asia" is an ideal that must be achieved. Through tri hita kirana-based videos all tourism potential can synergize well and be able to leave a stronger impression for watching. Therefore, tri hita kirana-based video as an audio visual dimension is an accurate and precise strategy. the public has satisfaction and pride in the existing tourism. The tri hita kirana concept which is the dimension of the video is very informative, persuasive, and touches on the emotions of teenagers, and society. The video that has been distributed via youtube has a positive appreciation from all community elements. It is hoped that this promotional video can contribute well to improving the quality and quantity of tourism in the Regency.

\section{References}

[1] A. Hermawan, Komunikasi Pemasaran. Jakarta: Erlangga, 2012.

[2] Muljadi, Kepariwisataan dan Perjalanan. Jakarta: PT Raja Grafindo Persada, 2009.

[3] P. Benyamin, "External Factors Evaluation," vol. 6, no. 1, pp. 5-9, 2017.

[4] R. I. G. Bagus, "Komunikasi pemasaran pariwisata dan perhotelan," Denpasar, 2016.

[5] and K. L. . Schiffman, L.G., Consumer Behavior. New Jersey: Prentice Hall, Inc., 1994.

[6] J. W. Creswell, Research Design: Pendekatan Kualitatif, Kuantitatif, Dan Mixed. Yogyakarta: PT Pustaka, 2010.

[7] K. R, Teknik Praktis Riset Komunikasi. Jakarta: Kencana Prenada Media Group., 2010 .

[8] W. Sudarta, "Penerapan Tri Hita Karana di Subak Kawasan Perkotaan (Kasus Subak Anggabaya, Kota Denpasar)," J. SOCA, vol. Vol. 9, No, 2008.

[9] N. R., Media Sosial. Bandung: Simbiosa Rekatama Media, 2015. 